\title{
PERCEPTIONS OF THE NURSING STAFF REGARDING THE SAFETY OF ELDERLY PATIENTS IN THE CARDIAC COMPUTED TOMOGRAPHY WITH CONTRAST ${ }^{1}$
}

\author{
Laura Vargas Acauan², Maria Cristina Soares Rodrigues ${ }^{3}$
}

\footnotetext{
${ }^{1}$ Excerpt from the dissertation "O idoso no Centro de Diagnóstico por Imagem: segurança na realização da angiotomografia coronariana", submitted to the Nursing Graduate Program (PPGEnf) of the University of Brasília (UnB), 2013.

${ }^{2}$ M.Sc. in Nursing by the PPGEnf/UnB. Scholarship by Coordination for the Improvement of Higher Education Personnel (CAPES), 2012. Federal District, Brazil. E-mail: lacauan@uol.com.br

${ }^{3}$ Ph.D. in Health Sciences. Associate Professor at the Nursing Department and the Nursing Graduate Program of UnB. Federal District, Brazil. E-mail: mcsoares@unb.br
}

\begin{abstract}
Descriptive study, with qualitative approach, in order to understand the perception of the nursing staff regarding the safety of elderly patients in the administration of iodinated contrast media, conducted at the diagnostic imaging centers of two private hospitals, located in Brasília, Federal District, Brazil. Data were collected by technical interview of eleven participants, between July and August 2012. The analysis and processing of the data were made by means of the method of content analysis, bringing out the safety category of the elderly in the realization of cardiac computed tomography - coronarian angiography. The nursing staff understood that the safety of the elderly in the exam is associated with the ability to assess risks for adverse events related to the administration of the radiopharmaceutical, in which processes, technologies and human interactions intertwine, implying in safe practices.
\end{abstract}

KEYWORDS: Diagnostic imaging. Contrast media. Patient safety. Aged. Nursing care.

\section{PERCEPÇÕES DA EQUIPE DE ENFERMAGEM SOBRE SEGURANÇA DO IDOSO NA TOMOGRAFIA COMPUTADORIZADA CARDÍACA CONTRASTADA}

RESUMO: Estudo descritivo, de abordagem qualitativa, com objetivo de compreender a percepção da equipe de enfermagem sobre segurança do idoso na administração do meio de contraste iodado. A coleta de dados foi realizada por entrevista gravada, de julho a agosto de 2012, com onze participantes, em dois centros de diagnóstico por imagem de hospitais privados de Brasília, Distrito Federal. A análise e tratamento dos dados se deram pela análise de conteúdo, emergindo a categoria segurança do idoso na realização da tomografia computadorizada cardíaca - angiotomografia coronariana. Conclui-se que a equipe de enfermagem entende que a segurança do idoso na realização do exame está associada à sua capacidade de avaliar riscos para ocorrência de reações adversas relacionadas à administração do radiofármaco, em que se entrelaçam processos, tecnologias e interações humanas, implicando práticas seguras.

PALAVRAS CHAVE: Diagnóstico por imagem. Meios de contraste. Segurança do paciente. Idoso. Cuidados de enfermagem.

\section{PERCEPCIONES DEL EQUIPO DE ENFERMERÍA SOBRE LA SEGURIDAD DEL PACIENTE ANCIANO EN LA TOMOGRAFIA CARDIACA COMPUTADORIZADA CONTRASTADA}

RESUMEN: Estudio descriptivo, abordaje cualitativo, con objetivo de conocer la percepción del cuadro de enfermería sobre la seguridad de ancianos en la administración de medios de contraste yodados. La recolección de datos fue por medio de entrevista, de julio a agosto de 2012, con once participantes, en centros de diagnóstico por imagen de dos hospitales de Brasilia, Distrito Federal, Brasil. El análisis y procesamiento de datos siguió el análisis de contenido, surgiendo la categoría seguridad de los ancianos en la realización de la tomografía cardiaca computadorizada. Se concluye que el cuadro de enfermería entiende que la seguridad de los ancianos se asocia con su capacidad de evaluar los riesgos de reacciones adversas en la administración del radiofármaco, en que se entrelazan procesos, tecnologías e interacciones humanas, lo que implica en prácticas seguras.

PALABRAS CLAVE: Diagnóstico por imagen. Medios de contraste. Seguridad del paciente. Anciano. Cuidados de enfermería. 


\section{INTRODUCTION}

Currently, technology applied to health, such as Imaging Diagnosis (ID) offers an array of options for laboratory investigation exams, which have become a rather requested practice by physicians. The ID contributes to the therapeutic area and preventively allows detection of changes, when the symptoms of certain diseases are not present yet. ${ }^{1}$ It is a specialty in which nursing workers provide assistance before, during and after the exam.

As a consequence of the vertiginous technological advance in this specialty of the health area, the Multiple Detector Computed Tomography (MDCT) emerges, which allows quick acquisition of accurate images of the coronarian arteries by means of an exam called coronarian angiotomography. This test helps the diagnosis of Coronary Artery Disease (CAD), the leading cause of death among the population in developed countries and in many developing countries. ${ }^{2}$

Despite the decline in recent decades, cardiovascular diseases are also the leading cause of morbidity and mortality in Brazil. Therefore, the Cardiac Computed Tomography (CT) - coronarian angiotomography is requested as an early and non-invasive diagnostic exam, with the purpose of preserving and providing life quality to elderly individuals who are affected by the narrowing of the vessels that supply the heart's blood needs, especially the coronarian arteries, in addition to controlling and following-up the treatment of already diagnosed cardiac diseases. ${ }^{2}$

To perform the CT - coronarian angiotomography, the intravenous administration of iodinated contrast media (radiopharmaceutical) is critical, which allows better view of the tissues, vessels and lesions. Nevertheless, possible adverse events (AEs) may occur in this procedure, such as allergic reactions, overflow, nephropathy induced by its use and drug interactions. ${ }^{3}$ Although it is known that this exam is very useful, it is important to consider potential hazards involving its execution, especially in the elderly. Thus, to avoid possible AEs, technical and scientific preparation are of fundamental importance on the part of the professionals, aiming at providing humanized, safe and

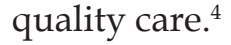

The safety and quality of care to patients in health services currently assume an important role, recognized as the "Age of Safety." The World Health Organization (WHO), ${ }^{5}$ through Resolution
55.18 , requires member states, including Brazil, to turn their attention to the safety of patients. ${ }^{6}$ Thus, in the context of a Diagnostic Imaging Center (DIC), the patient's safety must always be a priority, especially in elderly patients, increasing users of this health care service, as data have indicated that $80 \%$ of them have, at least, one chronic disease and require more frequent medical and therapeutic care.

Considering the relevant aspects presented, the object of this study is the analysis and understanding of the nursing staff on safety in administrating iodinated contrast in elderly individuals to perform the CT - coronary angiotomography.

Therefore, this study is justified by the increase in the prevalence and consequences of CAD in the elderly, since the aging of the population is a worldwide phenomenon, with projection for the year 2025 of 1.2 million people over 60 and many elderly at 80 or over will make up the highest growing age group. ${ }^{5}$

On the other hand, nursing, which continually seeks to improve knowledge aiming at professional excellence, participates actively in the realization of imaging exams. The elderly constitute a clientele that requires special attention from this professional before, during and after completion of the angiotomography, given the vulnerability imposed by the aging process.

Furthermore, this study is relevant for the contribution that professional nurses and their team at DIC may bring to promoting patient safety in this service where there are increasing exams every day and because it is a new space for service management and for the administration of the nursing care process. Thus, research should be conducted in order to produce knowledge and skills to sustain their own competences in this setting of care/assistance, by employing interdisciplinary technologies of light, mild-hard and hard nature.

Hence, the following guiding question was established to perform this study: How does the nursing team that acts in the DIC understand the safety of elderly patients receiving iodinated contrast media in the realization of CT - coronarian angiotomography?

These are the aspects that concerned us and motivated the development of this investigation in order to understand the perception of the nursing staff on the safety of elderly individuals in the administration of iodinated contrast media. 


\section{METHODOLOGY}

The qualitative approach was adopted to perform the study, by means of the descriptive method. Semi-structured recorded interviews were applied as the technique for data collection. The survey was conducted in July and August of 2012 with the nursing staff of two DICs, which operate their activities, respectively, in two private hospitals located in Brasília, Federal District (FD).

The interview script was organized based on three questions directly related to the research objective, namely: a) How do you define the safety of the elderly patient in the administration of iodinated contrast at CT - coronarian angiotomography? b) Administering half iodinated contrast in the performance of the CT - coronarian angiotomography is fundamental to perform this exam. Does using this medication seem safe in an elderly patient? c) Why?

The inclusion criterion to participate in the study was: being a member of the nursing staff of the DIC, regardless of gender and age, with working time in the hospital sector over 90 days, since this is the period of expiration of trial contracts and the ideal deadline so that the employee is inserted into the service and ready to act. DIC employees who were in service for less than 90 days were excluded, in addition to those who refused to participate in the study, and who were on sick leave or on any other form of leave during the period of data collection.

After accepting the invitation to participate in the study, 11 professionals from the nursing team signed the Terms of Free and Informad Coment, through which the participants were provided with information on the objectives of the research, and the guarantee of anonymity and freedom to give up participating at any stage of the research.

The interviewees' statements were recorded on a portable digital device, an IC Recorder, which was later transferred to the computer in digital media format. With the help of the software Windows Media Player ${ }^{\circledR}$, the statements were transformed into text, thus enabling their analysis. To ensure anonymity of the participants, the interviews were identified in the order they were performed, with Arabic numbers.

The research project was approved by the Research Ethics Committee of the Faculty of Health Sciences, University of Brasília, under protocol number 006/12. Since it involved the participation of human beings, the study complied with the ethical aspects of Resolution 196/96 of the National Health Council / Ministry of Health. ${ }^{8}$

Data analysis was developed by means of the content analysis method, ${ }^{9}$ defined as a set of communication analysis techniques, which uses systematic and objective procedures to describe the content of the messages and points out three basic steps in the work that was performed, namely: pre-analysis, analytical description and inferential interpretation.

After conversion of the interviews into texts, the study pre-analysis began, with the purpose to operationalize and systematize the initial ideas, directing the development of the subsequent operations. Armed with the printed answers, the first reading was performed, in which the contents of the interviews was accessed. Four free readings were performed on the entire material in order to know the texts and understand their main ideas. Afterwards, the encoding processes were determined. Codification was elected through Arabic numbers, which were assigned to the codes in order to facilitate their location in the body of the text. The second phase was then initiated, relative to the exploration of the material obtained.

The material was organized and encoded based on the clipping, enumeration, classification and aggregation of Registration Units (RUs) present in the speeches of the study participants. The thematic analysis was adopted in this study, considering the RUs of semantic nature (theme) to handle the material. They were highlighted, coded and systematically transferred to a spreadsheet for the operation of content analysis, enabling the enumeration rule by simple frequency.

The following procedure consisted of a first grouping of RUs by similarity of meaning, the Meaning Units (MUs). The phase of classification and grouping of the themes by semantic analogy followed, originating the candidate themes to the category and, finally, the last grouping of themes gave rise to an analytical category, appropriate to the mutual exclusion criteria, homogeneity, relevance, objectivity and productivity.

\section{RESULTS AND DISCUSSION}

The study was conducted with 11 participants, namely two nurses and nine nursing technicians, who were all female. In Brazil, the majority of nursing professionals are female, accounting for $87.24 \%$ of the professionals. It is no different in 
the Federal District, where it accounts for $87.21 \%$ in total. ${ }^{10}$ The option for these two nursing staff categories was due to the possibility of obtaining a broader perception of this group as a labor force in the service of a DIC, and because in spite of having specific attributions, they follow an ethics code with equal fundamental principles for the practice of the profession.

Totaling 55 RUs, grouped into themes, the safety analytical category of the elderly was originated in the performance of the CT - coronarian angiotomography; built as of the following MUs: safety in the administration of medications; physiological changes in aging; physical safety of the elderly at the DIC; use of light technologies in the assistance at the DIC; and safe use of hard technologies at the DIC.

\section{Safety of the elderly in the performance of the Cardiac Computed Tomography - coronarian angiotomography}

In any hospital sector, patient safety consists of reducing hazards and unnecessary damage, associated with health care, up to an acceptable minimum, which corresponds to what is feasible given the current knowledge of resources available and the context in which care was performed in face of the risk of non-treatment or another treatment. Among the resources available, the use of medications is one of the most employed; however, adverse effects and related errors are frequent. ${ }^{11}$

The nursing staff recognizes it is essential for safety and quality of care being very careful during the examination phase, in which the injection of contrast medium is vital. They understand that, this way, damages to the patient can be avoided and quality images will be obtained, contributing to obtaining a safe diagnosis. This analysis is evident in the words of some interviewees: [...] safety... from the moment I puncture his vein I see that it will not overflow when I put him on the table here too, right at the time of injecting the contrast I keep watching if there will not be any reaction because the elderly is a little bit more fragile, I also ask him to relax for the exam to come out really good [...] (e1); we define his safety through an orientation of what is being done to him, being certain of the venous access, and at the time the contrast is administered (e7).

It is known that the iodinated contrast agent is a radio-opaque substance, so it is called radiopharmaceutical, capable of improving the resolution of images obtained in radiological examinations. The "ideal" contrast must not produce any adverse effect; however, there is no such substance yet. ${ }^{12}$

The foregoing statements confirm that these professionals are aware that the administration of medications at a DIC, such as the radiopharmaceutical and some vasodilators used in the case of altered heart rate (ideal $=60 \mathrm{bpm}$ ), is one of the largest nursing responsibilities. Thus, the team has the important attribution to prevent, understand and treat possible immediate or delayed adverse effects caused by drug administration. Although medication preparation is a procedure that requires complex knowledge, the nursing staff of hospitals often does it as a simple task, assigned equally to assistants, technicians or nurses, and understood as part of their routine. Thus, the improper handling of medications has attracted the attention of health professionals, due to its consequences, such as the aspects that may decrease the microbiological safety and therapeutic efficacy in intravenous medication therapy. ${ }^{11}$ Therefore, it is crucial for the nursing team to be aware of the form of action of the drugs and adverse effects that might derive from their administration. ${ }^{13}$

Adverse or unwanted effects resulting from the administration of iodinated contrast are classified as anaphylactic, with clinical manifestations such as hives, runny nose, hypotension with tachycardia, bronchospasm, laryngeal edema, and more severe manifestations such as shock and severe respiratory insufficiency and chemotoxic reactions, in which there is the feeling of heat, nausea and vomit, cardiac arrhythmia, hypertension, kidney insufficiency, convulsion, among others. ${ }^{12}$ In addition to these effects, the overflow of contrast is considered an important local adverse effect to the intravenous administration of this radio-opaque substance. Most overflows involve volumes less than $10 \mathrm{~mL}$ progressing without complications; however, higher values, such as $50 \mathrm{~mL}$ or more, can cause tissue damage in the vicinity of the puncture site and, rarely, also compartmental syndrome. ${ }^{14}$ In addition, nephropathy induced by contrast has a higher incidence on diabetic patients, in the elderly and in those with pre-existing kidney disease, when compared with the general population. ${ }^{15}$ The perception as to the elderly patient's safety in a situation of kidney dysfunction is identified in the statement of an interviewee: [...] visualization of the exam will get better with the contrast to see the coronarian arteries. The safety of the 
elderly patient is only at risk if he has kidney problems; if he does not have kidney problems, there is no problem, of any consequence for the patient [...] (e5). The nursing teams from both DICs also show confidence in relation to the administration of iodinated contrast, especially the non-ionic iodinated contrast, since it involves a safer radiopharmaceutical as to the occurrence of possible AEs, when compared to ionic iodinated contrast, although its cost still restricts its broad use at several centers. ${ }^{12}$ I think it is safe, yes [administration of contrast in the elderly], it is safe, yes, to start with this contrast is not a very heavy contrast. It is not ionic, it will not cause a lot of harm to the patient [...] (e1).

The following interviews show that the staff considers patients' safety as a priority, being aware that any care process is liable to adverse effects, especially when administering a radiopharmaceutical to an elderly patient. Although the nursing staff has no attribution, authority or autonomy to suspend or proceed with the execution of an exam, it is aware of the importance of questioning and discussing with the other members of the DIC's staff about the risk versus benefit in performing the $\mathrm{CT}$ - coronarian angiotomography, considering the patient's clinical condition and history. The safety of the elderly itself means...trying to minimize risks. For an exam to be beneficial and to see that there is no kind of intercurrence (e3); [...] the administration of the iodinated contrast media is safe in the elderly because there is no kind of problem as long as the staff itself [of the DIC] takes all necessary measures; this will reflect in a good exam ... causing reflections in the benefit of... in favor of the patient. [...] (e3); [...] this exam cannot be performed without contrast; it needs the contrast, and since it does, if the physician has requested, if it is good for his health, it will improve his quality of life, if he needs the contrast... [...] (e8).

The use of medications in the elderly requires caution in its prescription, since the number of nephrons decreases progressively until a decrease of approximately $50 \%$ has occurred at approximately 70 to 80 years of age. Clinically, this decrease causes a reduction in the ability to concentrate urine. As a result, older adults excrete drugs more slowly and have the chance of accumulating them in excess. ${ }^{16}$

The nursing staff demonstrates to know that the elderly require special attention, because these patients are at higher risk due to the change process in their pharmacokinetic profile, which predisposes them to adverse effect processes. It is known that the elderly often takes several drugs due to concomitant diseases, inherent to the aging process. With this practice, there are drug interactions (DI) among the main causes of drugrelated AEs, estimating that $6 \%$ to $10 \%$ are caused by improper combinations, which may result in an increase or decrease of the therapeutic effect expected and/or emergence of adverse effects. ${ }^{16}$ Hence, it is crucial to know their drug history so that possible adverse effects can be prevented. [...] in this case he has to do the exam without any kind of stress so there is no damage. [...] (e2); [...] not lose access because he has greater capillary fragility, [...] because of the many diseases that the elderly may have, he is a more sensitive patient, so we have to be more careful with him, both with accesses, diseases and how much medication he takes (e2).

Another essential aspect concerning the organizational culture in the concerns the physical safety of the elderly patient, as demonstrated in the following statement: [...] because the safety he will have as long as I am careful with him, to carry him on a stretcher or chair, from the stretcher to the chair, exchanging his clothes, at the time of meeting him at the front door inside here [DIC], not to slip, not to fall, not to lose access $[\ldots]$ (e2).

Administration of other medications may be prescribed during the examination, and there may be the need for handling sterile materials, patient monitoring, treatment of adverse effects and cardiopulmonary arrest in emergency situations. Therefore, it is necessary that professionals are also properly trained and skilled as to the complexity of working with ionizing radiation to which the patient is exposed, because angiotomography is based on X-ray emission. ${ }^{17}$

The nursing staff feels safer when working with a full staff and trained for the performance of their duties at the DIC, consisting of nurse, nursing technicians, technicians and technologists in radiology, in addition to medical radiologists. It is also believed that ID exams requiring administration of the radiopharmaceutical and/or other drugs conducted in hospitals are safer, according to the answers given in some of the interviews: [...] if you need the contrast, the contrast or any intravenous medication may have some risk of... we can guide on this, the staff is prepared and, if any allergy happens, the physician is already here and we give him an antiallergic medication immediately and forward him to the emergency unit $(\mathrm{e} 8) ;[. .$.$] administration of iodinated$ contrast media in the elderly is safe due to the fact that it is performed in the hospital and because there is a medical team present. We're always working with 
the physician, he does not perform the exam, but if we need, there is a physician [...] (e11); [...] administration of iodinated contrast media in the elderly is safe if you administer this contrast by following these safety rules. With the specialist doctor, since we have him at our side and watching, indicating the right way, the correct dose, infusion rate, I think it is safe by following all these rules, but it sure is safe $[. .].(\mathrm{e} 10) ;[\ldots]$ quite often when I do the contrast, here at dawn, in a coronarian emergency, there is no physician, technician [radiology], that does it, it is not very... like with... [name of the radiology technician]; for instance, she is already an expert at that. If anything happens, sometimes she helps and... but it is not always that the technician is agile and we are alone, sometimes we also go through a tough situation [...] (e9).

Moreover, the nursing staff understands the magnitude of the safety issue of elderly patients, correlating it to potential damage in care. For this reason, it is concerned with asserting care with safety and quality, as shown in the statement: [...] administration of contrast medium in the elderly is safe if proper care is taken. Check if the accesses are ok with a good patent, look at the medications that interfere with the contrast, also check your physician's advice and if you are getting everything right with the exam indication [...] (e2).

In the statement of some study participants, the concept of safety of elderly patients is associated with the physiological condition of these patients, possible chronic diseases, as expressed in the statements: [...] Safety is monitoring. His vitals, it is... the research we do before. About... it is any disease which he might have, a chronic illness. Use of medication; since medication will be administered, we have to see the relation that there can be between one and the other; it is the venipuncture in the elderly who are more debilitated. [...] (e10); [...] safety... to know whether he is allergic to any medications, if he has diabetes, his clinical history [...] (e11); [...] the administration of the contrast medium in the elderly patient is safe, depending on his condition. If he is a weakened patient, a renal condition influences a great deal too. This depends largely on his condition at the time of the examination [...] (e6); [...] so we have to be more careful with him, both with the accesses and with the disorders and medication he takes. Generally, patients are hypertensive, sometimes they are diabetic patients [...] (e2).

The lifestyle of the elderly, associated with the aging process, assumes the appearance of chronic diseases. The National Household Sample Survey (NHSS), conducted in 2003, shows that
$75.7 \%$ of the elderly in Brazil suffer from chronic diseases such as: back pain, arthritis or rheumatism, cancer, diabetes or hyperglycemia; bronchitis or asthma, hypertension, heart disease, depression, tuberculosis, chronic renal disease, or tendinitis and cirrhosis. ${ }^{18}$

The nurses at the DICs value and use the relationship process daily, establishing a relationship of bonding with the elderly during all phases of the examination, as they believe that by improving the nursing practice and winning the confidence of the patient, the possibility of obtaining important and trustworthy data on his health increases. Whether through the patient's written records in the hospital or through written and printed instruments (questionnaires), provided to the patient for completion upon arriving at the DIC of the outpatient/emergency patient, the staff evaluates possible risks in the intent to prevent possible AEs.

Technology and nursing care are interrelated, since nursing is committed to principles, laws and theories, and technology is the expression of this scientific knowledge, and in its own transformation. ${ }^{18-19}$ Based on the understanding that human labor is possible by means of the technologies it generates, it becomes necessary to think about the relation established between technology, the scientific world and men, in all senses and spaces. Health technologies are classified into three categories: hard technology, related to technological equipment, rules, routines and organizational structures; soft-hard technology, which includes all well-structured knowledge in the health care process; and light technology, which refers to the relationship technologies of production, communication, admission, bonds, autonomization. Although these categories are interrelated, the human being needs, especially, relationship technologies defined as soft, ${ }^{20}$ which are based on the production of relations of reciprocity and interaction necessary for the realization of care. ${ }^{21}$

In this sense, the team brings the interaction with the patient as a basic instrument of nursing care, to develop and improve know-how and be professional in order to contribute to his safety and quality diagnostic, monitoring all actions performed, whether to advise, inform, support, comfort or meet his basic needs. This perception is demonstrated in the interviews: [...] when the patient comes to me we have a questionnaire with very important information for me to evaluate the health of this patient appropriately, so we can say that is where 
I base myself on how we can and if we can continue this exam [...] (e4); [...] we define his safety through an orientation of what is being done to him, being certain of the venous access, and at the time the contrast is administered [...] (e7). [...] and always advising about feeling anything, we inform what he is going to feel, which is that bitter taste in the mouth, and some burning. You will feel some burning beginning from the throat and going down and if you have anything else, raise your arm, tell us what you are feeling and we will stop [contrast injection and the machine] immediately [...] (e8); Explaining to him:what will happen, what will... what he might feel, asking if he already took the exam, if he ever had an allergic reaction, explaining what he can feel with the contrast ... and if he has asthma, [...] there is the questionnaire that we fill, then through the questionnaire we will get to see if the patient has asthma, these things, if he has diabetes $[. .$.$] (e9).$

Hard technology, which refers to the complex instrumental as a whole, encompassing all equipment used for treatments, examinations and organizing information ${ }^{21}$, is generated at the DIC. Thus, the nursing staff needs more than technical and scientific knowledge and it is part of its performance to monitor and interact with the patient and escort during his stay in that environment. ${ }^{20}$ Thus, the higher the level of complexity of a procedure, the easier it is for the health professional to protect himself behind these hard procedures and technologies. ${ }^{22}$

Regarding safety in the administration of radiopharmaceutical procedures, the injection is performed by the injection pump through peripheral venous access punctured by nurses, using a flow rate of $3.5 \mathrm{~mL}$ to $6 \mathrm{~mL} / \mathrm{s}$, which can be adjusted depending on the weight of the patient. The venipuncture should be done preferably in the right arm into a large vein, and vital signs should be measured, including blood pressure, heart and respiratory rate. ${ }^{2}$ The amount of the contrast medium injected is $80 \mathrm{~mL}$ to $120 \mathrm{~mL}$, with a iodine concentration of $350 \mathrm{mg} / \mathrm{mL}$ for this exam, in particular. [...] I think the procedure itself is safe; what I think that should be safer is the injection pump, because, for example, that pump, we have here, it does not lock, if you do not check, it injects. The pump should have a locking system when there is an overflow [...] (e6).

With respect to the injection pump, which is hard technology, a study performed in the United States tested an accessory device to detect overflow in automated injections of contrast medium, by the injector pump.22 This device consists of a flex- ible adhesive electrode that is placed on the arm of the patient designed to detect and interrupt intravenous injections in case of contrast medium overflow up to a limit of $10 \mathrm{~mL}$, and to interrupt the injection before reaching a volume of $20 \mathrm{~mL}$. The device is especially useful for high flow applications and in patients who have increased risk for extravasations. Nevertheless, more studies are needed for further confirmation and to check if the professionals could help monitor, inside the examination room, the contrast injection. ${ }^{23}$

At the DICs of the hospitals analyzed in this study, the professionals did not use any such device, which does not diminish the concern of the team with the infusion time. As per the following statement, the nursing technique manually tests the condition of venipuncture, being very attentive when the injection pump is driven to infuse the contrast medium: [...] making sure of the vein. If the access is okay, we will do the test, when we pick up the vein, we inject, see how the pulse is, then there is also the test in the room, we inject much stronger at the pump. And that is safe because [...] after the contrast of the serum into the pump, then we get out [of the tomography room], the contrast actually is there, we made sure twice if the vein is okay [...] (e8).

For the DICs to achieve an acceptable level of safety and quality, the Ministry of Health established a set of guidelines, through resolution $453 / 98$, which determines the need for a program of quality assurance in ID. This program requires the compliance with a number of items such as radiometric surveys in neighboring rooms to the radiological rooms, radiation leakage tests of $X$-rays ampoules, quality test of control equipment, certifications from the Brazilian School of Radiology (CBR), and increase in the number of institutions that request the certification from the National Accreditation Organization (NAO) $\cdot{ }^{24}$ In addition, it is recognized that safety culture components must be adopted to prevent risks, which base the DIC organization, with systemic focus, such as the operation of the risk management program, cultural awareness of the professionals to patient's safety, use of reliable indicators to measure the level of safe performance in the service, establishment of notification-protected systems, communication and analysis of incidents, among others.

\section{CONCLUSION}

A fast evolution in CAD's diagnostic resources has been observed, and coronarian angiotomography emerges as an imaging test of 
high diagnostic accuracy. Accordingly, the staff believes that this imaging test has contributed favorably to diagnose heart diseases, enabling the promotion and protection of health in the elderly. Moreover, it understands that the administration of the radiopharmaceuticals to perform the exam is essential and feels safer to be administering a drug considered the safest, i.e., the non-ionic drug. While recognizing this as a safety factor for contrast administration, it shows no satisfactory knowledge regarding the pharmacokinetics and pharmacodynamics of this radiopharmaceutical. Therefore, it is necessary to promote permanent nursing staff education, specifically in the field of pharmacology, since it is essential to have knowledge for the daily practice in a DIC.

Furthermore, it is important to emphasize that the understanding of the nursing staff about safety of the elderly in the exam involves the possibility of occurrence of possible AEs and therefore damage, due to the fact that the elderly present physiological changes resulting from loss of functional capacity that compromise his health. Moreover, the staff is aware of the risks involved in the exam, thus, they scrutinize possible risk factors for the elderly patient and escort, checking the information provided, listed in the questionnaire completed by the patient and/or escort upon being admitted at the DIC.

Considering the discourse of the interviewees in this study, we believe that the nursing staff is able to identify signs of possible systemic or local adverse effects and act, because it understands that, taking appropriate action, elderly patients will be safe. Thus, because of the interaction with the patient, it creates a space for exchange, speeches and hearing, applying light technology, which helps reduce risk and as a result of this lively work in a process of relationships, conducting a safe and quality examination. The hard technology produced at the DIC has been well used by nursing, despite being highly complex, with high technology and high cost, which does not interfere in team participation in humanized care for elderly patients.

Another aspect that should be considered in this research refers to the finding of lack of nursing publications on the subject, which requires the development of new studies that contribute to knowledge and information. From this path, health organizations will be provided with nurses prepared for management, care and research in DICs, striving for patient safety and service quality.

\section{REFERENCES}

1. Medicina em Goiás [pagina na internet]. Goiânia (GO): Medicina em Goiás. 2012 [acesso 2012 Out 22]. Disponível em: http:/ / www.medicinago.com. br/materia/740-diagnostico-por-imagem-riscos-ebeneficios

2. Silva LS. Avaliação da tomografia computadorizada com 64 colunas de detectores em pacientes com síndrome coronária aguda [tese]. São Paulo (SP): Faculdade de Medicina da Universidade de São Paulo. Programa de Cardiologia; 2011.

3. Rousseff P. Avaliação do risco para nefropatia induzida por contraste iodado após exames de imagem em hospital terciário [dissertação]. Belo Horizonte (MG): UFMG/Programa em ciências aplicada à saúde do adulto; 2010.

4. Rosa JRC, Queiroz FCB, Queiroz JV, Hekis HR, Pereira FB. Gestão da qualidade em um setor de radiologia hospitalar: um estudo no centro de diagnóstico por imagem (Santa Catarina). R-BITS [online]. 2011 [acesso 2012 Set 22]. Disponível em: http://ufrn. emnuvens.com.br/reb/article/view/1492

5. Organização Mundial da Saúde (OMS). The world health report. Geneva (CH): OMS; 2001.

6. Cassiani SHB, Gimenes FRE, Monzani AAS. O uso da tecnologia PR segurança do paciente. Rev Eletr Enf [online]. 2009 [acesso 2012 Ago 10]. 11(2): Disponível em: http://www.fen.ufg.br/revista/ v11/n2/pdf/v11n2a24.pdf

7. Centro de informações medicamentos-SUS. Informativo da Secretaria Municipal de Saúde. Uso de medicamentos pelo idoso. São Paulo (capital). 2003 Fev-Mar; 1(1):1-4.

8. Conselho Nacional de Saúde (BR). Resolução n.196 de 10 de outubro de 1996. Dispõe sobre diretrizes e normas regulamentadoras de pesquisas envolvendo seres humanos. Bioética. 1996; 4(Supl2):15-25.

9. Bardin L. Análise de conteúdo. São Paulo (SP): Edições 70; 2011.

10. Conselho Federal de Enfermagem (BR), Comissão de business intelligence Produto 2: análise de dados dos profissionais de enfermagem existentes nos Conselhos Regionais. Brasília (DF): Cofen; 2011.

11. Camerini GF, Silva DL. Segurança do paciente: análise do preparo de medicação intravenosa em hospital da rede sentinela. Texto Contexto Enferm. 2011 Jan-Mar; 20(1):41-9.

12. Colégio Brasileiro de Radiologia (CBR). Assistência à vida em radiologia. Guia teórico-prático. $1^{\mathrm{a}} \mathrm{ed}$. São Paulo (SP): Briefing Assessoria de Imprensa s/c ltda; 2000.

13. Fakih TF, Freitas GF, Secoli SR. Medicação: aspectos ético-legais no âmbito da enfermagem. Rev Bras Enferm. 2009 Jan-Fev; 62(1):132-5.

14. Martin WR. Safe and appropriate use of iodinated radiographic contrast agents: is there a reason to use 
high osmolality iodinated contract agents? Hosp Pharm. 2001 Aug; 36(8):836-42.

15. Malibroski A, Zukowski P, Nowicki G, Boguslawska R. Contrast induced nephropathy- a review current literature and guidelines. Med Sci Monit. 2011 Sep; 17(9):199-204.

16. Secoli SR, Danzi NJ, Lima FFF, Filho GL, Cesar LAM. Interações medicamentosas em pacientes coronariopatas. Rev Bras Cardiol. 2012 Jan-Fev; 25(1):11-8.

17. Bianco RPR, Araújo ES. Nefroproteção relacionada ao uso de meio de contraste iodado: atenção de enfermagem. Acta Paul Enferm. 2008; 21(Esp):187-91.

18. Ministério do Planejamento (BR), Orçamento e Gestão (BR). Indicadores sócio-demográficos e de saúde do Brasil. Brasília (DF): Instituto Brasileiro de Geografia e Estatística; 2009.

19. Rocha PK, Prado LM, Wal LM, Carraro TL. Cuidado e tecnologia: aproximações através do modelo de cuidado. Rev Bras Enferm. 2008 Jan-Fev; 61(1):113-6.

20. Merhy EE. Em busca do tempo perdido: micropolítica do trabalho vivo em saúde. In: Onocko R, Merhy EE, organizadores. Agir em saúde: um desafio para o público. São Paulo (SP) - Buenos Aires (AR): HUCITEC - Lugar Editorial; 1997.

21. Silva DC, Alvim NAT, Figueiredo PA.Tecnologias leves em saúde e sua relação com o cuidado de enfermagem hospitalar. Esc Anna Nery Rev Enferm. 2008 Jun; 12(2):291-8.

22. Merhy EE. O desafio que a educação permanente tem em si: a pedagogia da implicação. Comunic Saúde Educ [online]. 2005 [acesso 2012 out 27]. Disponível em: http://www.scielo.br/pdf/icse/ v9n16/v9n16a15.pdf

23. Birnbaunm BA, Nelson RC, Chezmar JL, Glick SN. Extravasation Deteccion Acessory: Clinical Evaluation in 500 patients. Radiology. 1999 Ago; 212(2):431-38.

24. Ministério da Saúde (BR). Secretaria de Vigilância Sanitária. Portaria Federal 453, de $1^{\circ}$ de Junho de 1998: Regulamento Técnico que estabelece as diretrizes de proteção radiológica em radiodiagnóstico médico e odontológico. Brasília (DF): MS, 1998. 